Research paper

\title{
Lambs fed cassava silage with added tamarind residue: Silage quality, intake, digestibility, nitrogen balance, growth performance and carcass quality
}

\author{
C.M. Souza ${ }^{a}$, R.L. Oliveira ${ }^{a, *}$, T.V. Voltolini ${ }^{\mathrm{b}}$, D.R. Menezes $^{\mathrm{c}}$, N.J.A. dos Santos ${ }^{\mathrm{a}}$, \\ A.M. Barbosa ${ }^{\text {a }}$, T.M. Silva ${ }^{\text {a }}$, E.S. Pereira ${ }^{\mathrm{d}}$, L.R. Bezerra ${ }^{\mathrm{e}}$

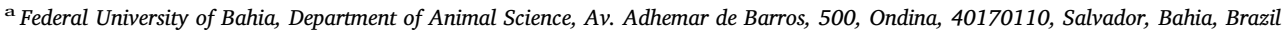 \\ b Brazilian Agricultural Research Corporation, Embrapa Semi-Arid, BR-428, Km 152, s/n - Rural Zone, 56302970, Petrolina, Pernambuco, Brazil \\ ${ }^{c}$ Federal University of São Francisco Valley, Rodovia 407, 12 Lot 543 - Irrigation Project Nilo Coelho - S/N C1, 56300000, Petrolina, Pernambuco, \\ Brazil \\ ${ }^{\mathrm{d}}$ Federal University of Ceará, Department of Animal Science, Ac. Público, 825, Pici, 60021970, Fortaleza, Ceará, Brazil \\ ${ }^{\mathrm{e}}$ Federal University of Piaui, Department of Animal Science, Rodovia Bom Jesus-Viana, km 135, 64900000, Bom Jesus, Piaui, Brazil
}

\section{A R T I C L E I N F O}

\section{Keywords:}

Additive

Carcass

Fiber

Gases

Tamarindus indica

\begin{abstract}
A B S T R A C T
The objective of this study was to evaluate the effects adding tamarind residue to cassava silage on the quality of the silage and its in vitro ruminal fermentation, as well as the growth performance and carcass quality of lambs. A completely randomized design with four inclusion levels $(0.00,100,200$ and $300 \mathrm{~g} / \mathrm{kg}$ ) of tamarind residue (Tamarindus indica L.) added to cassava silage was used. Twenty mini-silos were used to prepare samples of the four treatments (five replicates each), which were opened after 56 days. Forty male lambs were fed cassava silage with added tamarind residue as the roughage and a concentrate (500:500 $\mathrm{g} / \mathrm{kg}$ of feed) over 85 days. There was no effect of the tamarind residue-added cassava silage on effluent losses and dry matter (DM) recovery rates. However, there were linear and quadratic reductions in $\mathrm{pH}(P<0.001)$ and the crude protein (CP) $(P<0.001)$, ether extract (EE) $(P<0.001)$ and ash $(P<0.001)$ contents and linear and quadratic increases in the DM, neutral detergent fiber (NDF) $(P<0.001)$, acid detergent fiber (ADF) $(P<0.001)$, non-fibrous carbohydrate (NFC) $(P<0.001)$, acid detergent lignin (ADL) $(P<0.001)$, and tannin $(P<0.001)$ contents. There was a linear increase in the maximum potential gas production from total carbohydrates and the gas production rate from NFCs $(P<0.001)$. The production rate of total gases $(P<0.001)$, lag phase duration $(P<0.001)$ and DM in vitro degradability $(P<0.001)$ were all reduced with the addition of tamarind residue in silage. There was no effect of the tamarind residue-added cassava silage on $\mathrm{DM}, \mathrm{CP}, \mathrm{NFC}$ or total digestible nutrient (TDN) intakes $(\mathrm{g} / \mathrm{d})$. However, there was a linear increase in the NDF intake $(P=0.042)$ and a linear reduction in the EE $(P=0.038)$ intake by lambs. There was an increase in the DM $(P<0.001)$, CP $(P<0.001)$, and NDF $(P<0.001)$ contents. There was linear effect on the DM $(P<0.001)$, CP $(P<0.001)$, and NDF $(P<0.001)$ contents and a positive quadratic on EE $(P=0.018)$ digestibility. There was linear
\end{abstract}

\footnotetext{
Abbreviations: ADF, acid detergent fiber; ADG, average daily gain; ADL, acid detergent lignin; CCW, cold carcass weight; CCY, cold carcass yield; CP, crude protein; DM, dry matter; DMI, dry matter intake; EE, ether extract; FCs, fibrous carbohydrates; GC, gastrointestinal tract contents; HCW, hot carcass weight; HCY, hot carcass yield; IVDMD, in vitro dry matter digestibility kinetics over $48 \mathrm{~h}$; LDA, longissimus dorsi area; $\mathrm{NDF}_{\text {ap }}$, neutral detergent fiber corrected for ash and protein; $\mathrm{m}_{1}$, gas production rates from non fibrous carbohydrates; $\mathrm{m}_{2}$, gas production rates from fibrous carbohydrates; mt, total gas production rate; NFCs, non-fibrous carbohydrates; TDNs, total digestible nutrients; $\mathrm{vf}_{1}$, maximum potential gas production from non-fibrous carbohydrates; vf $\mathrm{f}_{2}$, maximum potential gas production from fibrous carbohydrates; vt, maximum potential gas production from total carbohydrates

* Corresponding author.

E-mail addresses: ronaldozootecnista@gmail.com, ronaldooliveira@ufba.br (R.L. Oliveira).
} 
increase in nitrogen $(\mathrm{N})$ fecal excretion $(P<0.001)$ and a quadratic decrease in $\mathrm{N}$ urinary $(P=0.018)$ excretion and $\mathrm{N}$ retention $(P<0.001)$. There was an increase in the hot and cold carcass weights and yields $(P<0.001)$ and in the Longissimus dorsi area (LDA) $(P<0.001)$ of the lambs. The addition of $300 \mathrm{~g} / \mathrm{kg}$ tamarind residue to cassava silage is recommended because it reduces the production of gases and improves the DM content of the diet. In addition, this diet increases the DM in vitro digestibility and intake (DMI), $\mathrm{N}$ retention, hot and cold carcass yields, and LDA of lambs.

\section{Introduction}

Ensiling cassava (Manihot esculenta, Crantz.) is an important method of fodder preservation for maintaining the diets of animals during periods of shortage. Howeverthe low use of cassava silage in animal feed is related to the lack of knowledge of its nutritional levels and the actual potential of crop residues for use in the feeding and production of ruminants (Silva et al., 2015a; Polyorach et al., 2016). In addition the use of cassava silage is limited by its low dry matter (DM) content (220-250 g/kg) which causes difficulties in fermenting the silage (Santos et al. 2015). Another important factor relevant to the ensiling process is the high crude protein (CP) content of cassava (205 g/ $\mathrm{kg} \mathrm{DM})$ which can lead to a buffering effect that hinders the reduction of the pH to levels optimal for silage fermentation (Fernandes et al., 2016; Ampapon et al., 2016). Thus residues originating from the agro-industry are under consideration for use as additives to silage forage plants that can increase DM content and reduce the risk of losses via undesirable fermentation (Gonzaga Neto et al., 2015 ; Oliveira et al., 2015a).

In this respectthe tamarind (Tamarindus indica L) a member of the Fabaceae family is one potential additive (Geron et al., 2015). This plant originates in Africa but can currently be found in many tropical countries. The pulp of its fruit is edible and the tamarind processing industry generates tamarind residues after the drying process (Wang et al., 2016). Therefore it was hypothesized that because of its chemical composition (DM $=880 \mathrm{~g} / \mathrm{kg}$ feed and $\mathrm{CP}=75 \mathrm{~g} / \mathrm{kg} \mathrm{DM}$ ) dried tamarind residue could be added at up to $300 \mathrm{~g} / \mathrm{kg}$ as an additive to improve cassava silage and reduce losses due to fermentation and that this silage could be used as a lamb diet where it would increase feed intake and digestibility and improve nitrogen $(\mathrm{N})$ balance growth performance and carcass quality of lambs. The objective of this study was to determine the most effective level at which to add tamarind residue to cassava silage for improving the chemical composition and quality of the silage and to determine what effect this had on feed intake and degradability and on $\mathrm{N}$ balance growth performance and carcass quality of lambs fed this silage.

\section{Materials and methods}

This study was carried out in strict accordance with the recommendations in the Guide of the National Council of Brazil for the Control of Animal Experiments of the Federal University of Bahia, Bahia State, Brazil (Permit Number: 0002/140814).

\subsection{Silage and treatments}

The cassava used in the silage consisted of the above-ground biomass (manioc + leaf) of the Recife variety harvested after approximately six months of cultivation. Cassava silage was produced in an irrigated system and grown with $1.0 \mathrm{~m}$ between plants and $1.2 \mathrm{~m}$ between rows. After harvest and transport, the above-ground biomass was crushed into 3- to 4-cm pieces with the aid of sieves contained in a fodder machine. Tamarind residue was obtained from plants used in the tamarind pulp manufacturing industry, and it was dried in the sun for approximately $12 \mathrm{~h}$ to reach a DM content of approximately $850 \mathrm{~g} / \mathrm{kg}$. It was then ground into a meal using a forage machine with a 3-mm-diameter sieve.

After drying, the tamarind residue was mixed with the above-ground biomass of cassava to obtain a homogeneous mixture. To make the mini-silos (five replicates per treatment), polyvinyl chloride (PVC) tubes $100 \mathrm{~mm}$ in diameter and $50 \mathrm{~cm}$ in length (5-L capacity) were used. They had a Bunsen-type valve on the lid for the output of gases from the silo and a sand chamber for wastewater collection.

The treatments varied according to the levels of tamarind residue added $(0.00,100,200$ or $300 \mathrm{~g} / \mathrm{kg}$ of feed) to the natural silage material. Cassava silage with tamarind residue added in the same proportions as prepared in the mini-silos was also prepared in barrels with a 200-L capacity (Poliembalagens ${ }^{\oplus}$, São Paulo, Brazil). The material was compacted by trampling, and the barrels were sealed with a lid using a metal seal. The mini-silos were packed with the aid of a wooden plunger and filled to a density of $600 \mathrm{~kg} / \mathrm{m}^{3}$. Then, each pipe was closed with a PVC cap and sealed with plastic tape (Poliembalagens ${ }^{\varpi}$, São Paulo, Brazil). The large barrels and mini-silos were stored in the shade at a temperature between 20 and $25{ }^{\circ} \mathrm{C}$ and were opened after 56 days.

After opening the mini-silos, the $\mathrm{pH}$ was measured with a $\mathrm{pH}$ meter (MA522 model, Marconi Laboratory Equipment, Piracicaba, Brazil). The effluent losses were quantified using the following equation proposed by Jobim et al. (2007): E (kg/t FM) = [(TWo - TWs $) /($ GMef $)] \times 100$, where $\mathrm{E}=$ effluent yield $(\mathrm{kg} / \mathrm{t} \mathrm{FMs),} \mathrm{FMs} \mathrm{=} \mathrm{forage} \mathrm{mass} \mathrm{in} \mathrm{the} \mathrm{silage,} \mathrm{TWo}=$ total weight $($ silo + sand + sandbag) when the silos were opened $(\mathrm{kg})$ ) TWs = total weight (silo + sand + sandbag) when the silos were sealed (kg), and GMef = green mass of the ensiled forage $(\mathrm{kg})$. The gas losses were quantified using the following equation: $\mathrm{GL}(\mathrm{g} / \mathrm{kg} \mathrm{DM})=$ $[(\mathrm{SWs}-\mathrm{SWo}) /(\mathrm{FMs} \times \mathrm{DMe})] \times 100$, where GL $=$ gas losses during storage $(\mathrm{g} / \mathrm{kg}$ of initial DM), SWs = silo weight during the ensilaging process, SWo $=$ silo weight at opening, FMs $=$ forage mass in the silage, and DMe $=$ DM content of the forage in the 
silage. The DM recovery rate in the silage was determined by the method proposed by Jobim et al. (2007) using the following equation: $\operatorname{DMR}(\mathrm{g} / \mathrm{kg})=[(\mathrm{FMo} \times \mathrm{DMo}) /(\mathrm{FMc} \times \mathrm{DMc})] \times 100$, where $\mathrm{DMR}=\mathrm{DM}$ recovery rate, FMo $=$ forage mass at silo opening, DMo = DM content at silo opening, FMc = forage mass at silo closing, and DMc = DM content of the forage at silo closing. The ammonia $\mathrm{N}$ (mg/g total $\mathrm{N}$ ) content was determined as described by Bolsen et al. (1992). Samples of each mini-silo were dried in a forced-circulation oven at $55^{\circ} \mathrm{C}$ for $72 \mathrm{~h}$ and subsequently milled in a knife mill with a 1-mm sieve.

\subsection{In vitro trial using an in vitro gas production technique}

For kinetic assays of degradation and gas production, an in vitro semiautomatic technique of measuring gas production was conducted according to Mauricio et al. (2003) and modified by Menezes et al. (2015). Samples were dried in an oven with forced ventilation at $55^{\circ} \mathrm{C}$ for $72 \mathrm{~h}$ and ground in a mill with a 1-mm sieve; approximately $1 \mathrm{~g}$ of each sample of silage was incubated in glass jars $(160 \mathrm{~mL})$, and there were five replicates per treatment. To each vial, $90 \mathrm{~mL}$ of culture medium prepared according to Theodorou et al. (1994) was added manually; this medium had been previously reduced from aspersion with $\mathrm{CO}_{2}$ to adjust $\mathrm{pH}$ to within the range of 6.8-7.0. In addition, $10 \mathrm{~mL}$ of ruminal fluid collected directly from the rumen of two cannulated sheep was added to each vial. From the start, ruminal fluid was homogenized and packed in thermoses previously heated with water at $39{ }^{\circ} \mathrm{C}$ and then filtered through a double layer of gauze. The buffer solution and the inoculum were added under $\mathrm{CO}_{2}$ aspersion to ensure anaerobic conditions. Vials were immediately sealed with a rubber stopper, sealed and then kept in an incubator chamber at $39{ }^{\circ} \mathrm{C}$. Pressure readings were performed at $2,4,6,8,9,11,12,14,17,20,24,28,34,48,72,96$ and $120 \mathrm{~h}$.

Data obtained from the measurements of the cumulative production of gas were then subjected to the two-compartment model suggested by Schofield et al. (1994) as follows: $\mathrm{v}(\mathrm{t})=\left[\mathrm{vf}_{1} /\left(1+\mathrm{e}^{(2-4 \mathrm{~m} 1(\mathrm{lt})}\right)\right]+\left[\mathrm{vf}_{2} /\left(1+\mathrm{e}^{(2-4 \mathrm{~m} 2(\mathrm{lt})}\right)\right]$, where $\mathrm{v}(\mathrm{t})$ is the maximum volume of the total gases produced, $\mathrm{vf}_{1}$ represents the maximum gas volume fraction from the rapid degradation (from $\mathrm{NFCs}$ ), $\mathrm{vf}_{2}$ represents the maximum gas volume fraction from the slow degradation (from FCs), $\mathrm{m}_{1}$ equals the specific growth rate for the fraction from the rapid degradation, $\mathrm{m}_{2}$ is equivalent to the specific growth rate of the fraction from the slow degradation, lt is the lag time (or colonization time), and $\mathrm{b}\left(\mathrm{h}^{-1}\right)$ and $\mathrm{c}\left(\mathrm{h}^{-0.5}\right)$ are the constant fractional rates. The fractional rates $\left(\mathrm{h}^{-1}\right)$ combined with gas production $(\mu)$ were also calculated with the following equation: $\mu=b+c / Q_{2}$, wherein $\mu=$ the gas production rate $\left(h^{-1}\right)$, and $Q_{2}$ is the duration of the initial digestion events (the lag phase) common to the two phases.

The fermentation residues were obtained by filtration in crucibles of porosity 1 (Pirex, Vidrotec, São Paulo, Brazil), which were dried for $48 \mathrm{~h}$ at $100{ }^{\circ} \mathrm{C}$ and weighed to calculate the DM degradability (DMD) values. The DMD was estimated after $48 \mathrm{~h}$ of fermentation.

\subsection{Animal experiments and management}

Forty non-castrated male lambs of undefined breed that were vaccinated and dewormed (six months old, $22.1 \pm 3.00 \mathrm{~kg}$ BW (mean \pm SD) were used. The experiment used a completely randomized design that had 4 treatments and 10 replicates.

The animals were housed in a covered shed in individual $1.61-\mathrm{m}^{2}$ pens equipped with drinking fountains, feeders and salt shakers. The experimental period lasted 85 days, with 13 days allowed for adaptation to the installation, location and diet. The residue inclusion levels were increased gradually, with three days at each level of inclusion, so that the animals that received treatments with a greater level of inclusion also initially received the lower levels of residue inclusion in the silage.

The diets were offered twice daily, at 9:00 and 16:00 h, in the form of a total mixed ration with roughage and concentrate (500:500 g/kg of DM). The cassava + tamarind residue mixture $(0.00,100,200$ or $300 \mathrm{~g}$ of residue/ $\mathrm{kg}$ of DM included in the natural silage material) was used as roughage, and the concentrate was made from a cornmeal base with soybean meal. The provided feed and refused feed were weighed daily to monitor nutrient intake. Adjustments were made to ensure that the remains were between 100 and $200 \mathrm{~g} / \mathrm{kg}$ DM. Water and mineral salts were provided ad libitum.

Diets were formulated according to the recommendations of the National Research Council (NRC, 2007) to meet the nutritional requirements for crossbred lambs with estimated weight gains of $200 \mathrm{~g} /$ day. Samples of the ingredients and formulated diets were collected and examined to analyze of their chemical composition (Tables 1 and 2).

Samples (triplicate) were pre-dried at $55^{\circ} \mathrm{C}$ for $72 \mathrm{~h}$, ground with a Willey mill (Tecnal, Piracicaba City, São Paulo State, Brazil) with a 1-mm sieve, stored in airtight plastic containers (ASS, Ribeirão Preto City, São Paulo State, Brazil), and sealed properly until use in laboratory analyses of the levels of DM (method 967.03 - AOAC, 1990), ash (method 942.05 - AOAC, 1990), CP (method 981.10 - AOAC, 1990), and EE (method 920.29 - AOAC, 1990). The neutral detergent fiber (NDF) content was determined as described by Van Soest et al. (1991) and expressed as inclusive of residual ash, and heat-stable alpha-amylase was not used. Acid detergent fiber (ADF) contents were determined as described by Robertson and Van Soest (1981). Acid detergent lignin (ADL) contents were determined using the AOAC method 973.18 (2002) in which the ADF residue is treated with $72 \%$ sulfuric acid. To this end, the neutral detergent boiling residue was incinerated in an oven at $600{ }^{\circ} \mathrm{C}$ for $4 \mathrm{~h}$, and a correction for protein content was applied by subtracting the neutral detergent insoluble $\mathrm{N}$ content.

The non-fibrous carbohydrate (NFC) content of the ingredients was determined as described by Mertens (1997) and was calculated using the following equation: $\mathrm{NFC}=100-\mathrm{NDF}_{\mathrm{ap}}-\mathrm{CP}-\mathrm{EE}-$ ash, where $\mathrm{NDF}_{\mathrm{ap}}$ is neutral detergent fiber corrected for ash and protein. The neutral detergent insoluble $\mathrm{N}$ and acid detergent insoluble $\mathrm{N}$ values were obtained following the recommendations of Licitra et al. (1996) (Table 1).

To determine the total phenolic content, the conventional Folin-Ciocalteu spectrophotometric method developed by Singleton and Rossi (1965) was used. Aliquots $(100 \mu \mathrm{L})$ of extracts were added to $750 \mu \mathrm{L}$ of distilled water, $500 \mu \mathrm{L}$ of Folin-Ciocalteu reagent and 
Table 1

Ingredients and chemical composition of experimental diets.

\begin{tabular}{|c|c|c|c|c|}
\hline \multirow[t]{2}{*}{ Item } & \multicolumn{4}{|c|}{ Tamarind residue ( $\mathrm{g} / \mathrm{kg}$ as fed) } \\
\hline & 0.00 & 100 & 200 & 300 \\
\hline \multicolumn{5}{|l|}{ Ingredient proportions (g/kg DM) } \\
\hline Cassava silage with added tamarind residue & 500 & 500 & 500 & 500 \\
\hline Ground corn & 468 & 407 & 396 & 370 \\
\hline Soybean meal & 32.0 & 93.0 & 105 & 130 \\
\hline \multicolumn{5}{|l|}{ Chemical composition (g/kg DM) } \\
\hline Dry matter ( $\mathrm{g} / \mathrm{kg}$ as fed) & 266 & 303 & 375 & 425 \\
\hline Crude protein & 151 & 152 & 152 & 153 \\
\hline Ether extract & 38.8 & 31.2 & 28.6 & 27.3 \\
\hline Ash & 81.6 & 84.1 & 76.0 & 73.8 \\
\hline Neutral detergent fiber ${ }^{a}$ & 284 & 301 & 314 & 323 \\
\hline Acid detergent fiber & 169 & 198 & 207 & 218 \\
\hline Neutral detergent insoluble protein $(\mathrm{g} / \mathrm{kg}$ of $\mathrm{CP})$ & 132 & 131 & 132 & 128 \\
\hline Acid detergent insoluble protein $(\mathrm{g} / \mathrm{kg}$ of $\mathrm{CP})$ & 121 & 120 & 121 & 117 \\
\hline Acid detergent lignin & 26.1 & 53.8 & 71.4 & 84.4 \\
\hline Non-fibrous carbohydrates & 445 & 431 & 430 & 423 \\
\hline Total tannins (GAE mg/g DM) ${ }^{\mathrm{b}}$ & 12.9 & 19.2 & 23.9 & 27.3 \\
\hline
\end{tabular}

Table 2

Chemical composition, $\mathrm{pH}$, effluent loss, gas loss, dry matter recovery and ammonia nitrogen of the cassava silage with the tamarind residue additive after opening the silo after 56 days.

\begin{tabular}{|c|c|c|c|c|c|c|c|}
\hline \multirow[t]{2}{*}{ Item } & \multicolumn{4}{|c|}{ Tamarind residue ( $\mathrm{g} / \mathrm{kg}$ as fed) } & \multirow[t]{2}{*}{ SEM $^{\mathrm{a}}$} & \multicolumn{2}{|l|}{$P$-value } \\
\hline & 0.00 & 100 & 200 & 300 & & Linear & Quadratic \\
\hline Dry matter (g/kg as silage) & 280 & 318 & 395 & 448 & 16.0 & $<0.001$ & $<0.001$ \\
\hline Crude protein (g/kg DM) & 208 & 158 & 149 & 128 & 7.01 & $<0.001$ & $<0.001$ \\
\hline Ether extract (g/kg DM) & 34.4 & 21.3 & 16.3 & 14.6 & 2.04 & $<0.001$ & $<0.001$ \\
\hline Ash (g/kg DM) & 100 & 98.0 & 79.4 & 71.5 & 3.29 & 0.018 & 0.044 \\
\hline $\mathrm{NDF}_{\mathrm{ap}}^{\mathrm{b}}(\mathrm{g} / \mathrm{kg} \mathrm{DM})$ & 464 & 503 & 530 & 550 & 8.45 & $<0.001$ & $<0.001$ \\
\hline Acid detergent fiber (g/kg DM) & 310 & 363 & 380 & 400 & 8.88 & $<0.001$ & $<0.001$ \\
\hline Acid detergent lignin (g/kg DM) & 39.8 & 97.9 & 132 & 162 & 10.5 & $<0.001$ & 0.029 \\
\hline Non-fibrous carbohydrates (g/kg DM) & 194 & 219 & 225 & 235 & 5.21 & $<0.001$ & 0.058 \\
\hline Total tannins $\left(\mathrm{GAE}^{\mathrm{c}} / \mathrm{g} \mathrm{DM}\right)$ & 26.0 & 38.3 & 47.8 & 54.5 & 1.54 & $<0.001$ & $<0.001$ \\
\hline $\mathrm{pH}$ & 4.04 & 3.89 & 3.85 & 3.86 & 0.02 & $<0.001$ & $<0.001$ \\
\hline Effluent loss (kg/t FMs) ${ }^{\mathrm{d}}$ & 0.22 & 0.23 & 0.22 & 0.23 & 0.02 & 0.29 & 0.34 \\
\hline Gas losses (g/kg DM) & 12.3 & 15.6 & 21.4 & 21.1 & 15.0 & 0.059 & 0.15 \\
\hline Dry matter recovery $(\mathrm{g} / \mathrm{kg}$ of feed) & 990 & 991 & 991 & 991 & 30.0 & 0.30 & 0.34 \\
\hline Ammonia nitrogen $(\mathrm{mg} / \mathrm{g} \mathrm{N})$ & 41.2 & 34.3 & 36.2 & 29.3 & 14.0 & $<0.001$ & 0.99 \\
\hline
\end{tabular}

a Standard error of the mean.

b Neutral detergent fiber corrected for ash and protein content.

${ }^{\mathrm{c}} \mathrm{GAE}=$ gallic acid equivalent.

${ }^{\mathrm{d}} \mathrm{FMs}=$ forage mass in the silage.

$1000 \mu \mathrm{L}$ of $350 \mathrm{~g} / \mathrm{kg}$ sodium carbonate $\left(\mathrm{Na}_{2} \mathrm{CO}_{3}\right)$. The mixture was shaken vigorously after being diluted to $10 \mathrm{~mL}$ with distilled water. The mixture was incubated for $30 \mathrm{~min}$ at room temperature and read at $725 \mathrm{~nm}$ using a GENESYS 10S UV-vis spectrophotometer. Distilled water was used as the blank. Gallic acid standard solutions were prepared (Tamilselvi et al., 2012), and total tannin contents were expressed as GAE mg/g DM (GAE = gallic acid equivalent), as calculated from a standard curve prepared using 0-100 mg/GA (Table 1).

To determine the digestibility of the nutrients in the middle of the trial period, days 37-46, 24 animals were housed in metabolic cages ( 6 animals from each treatment at this stage). The animals went through an adjustment period of 7 days, and from days $44-46$, the orts, provided diet, feces and urine were collected daily. Collected samples were then frozen for further analysis. To collect total feces, appropriate bags were attached to the animals, and samples were collected twice a day, at 08:00 and 15:00 h. They were then weighed and homogenized, and approximately $100 \mathrm{~g} / \mathrm{kg}$ of the total sample volume was retained for subsequent laboratory analysis. Urine was collected using a bucket collector in the metabolic cage, which contained $0.036 \mathrm{~N} \mathrm{H}_{2} \mathrm{SO}_{4}$ in a proportion equal to $100 \mathrm{~g} / \mathrm{kg}$ of the total volume of urine from the previous day.

The DM digestibility coefficients (DMDCs) for CP, ether extract (EE), NDF, and NFCs were calculated using the equation: $\mathrm{DMDC}=[(\mathrm{kg}$ of ingested fraction $-\mathrm{kg}$ of excreted fraction $) /(\mathrm{kg}$ of fraction ingested $)] \times 100$. The $\mathrm{N}$ contents of the triplicate 
samples of the provided diet, feces and urine were determined according to the methodology described by the AOAC (1990). The retention of $\mathrm{N}$ ( $\mathrm{N}$ retained, $\mathrm{g} / \mathrm{d})$ was determined using the following formula: $\mathrm{N}$ retained $(\mathrm{g} / \mathrm{g})=\mathrm{N}$ intake $(\mathrm{g} / \mathrm{d})-[\mathrm{N}$ feces excretion $(\mathrm{g} / \mathrm{d})+\mathrm{N}$ urine excretion $(\mathrm{g} / \mathrm{d})]$.

The nutrient intake was determined by subtracting the amount of each nutrient contained in the refusals from the total of each nutrient in the feed offered. The animals were individually weighed at the beginning of the experiment and again every 21 days to determine the performance of lambs and their average daily gain (ADG). The weight measurements were performed in the morning before the first daily feeding and after a continuous fasting period of approximately $16 \mathrm{~h}$.

Feed conversion (feed/gain) was determined using the average dry-weight intake of lambs fed the different diets divided by their ADG, which was calculated based on the difference in the initial and final body weights of animals divided by the number of days in the trial period. Values were expressed as $\mathrm{g} / \mathrm{g}$.

At the end of the experiment, the animals were fasted for $16 \mathrm{~h}$ and then weighed to determine their slaughter weight. Later, the animals were stunned with a pneumatic pistol and bled. After slaughter, the gastrointestinal tract contents (GC) were removed to determine the empty body weight. After skinning, gutting, and the removal of the head, feet and genitals, the hot carcass weight (HCW, kg) was obtained. The carcasses were cooled in cold storage for $24 \mathrm{~h}$ at $4{ }^{\circ} \mathrm{C}$ and then weighed to determine the cold carcass weight (CCW, kg). Using these data, the hot carcass yield (HCY) and cold carcass yield (CCY) were calculated based on the carcass weight relative to the body weight at slaughter $(\mathrm{g} / \mathrm{kg})$.

Cooling losses $[\mathrm{CL}(\mathrm{g} / \mathrm{kg})=(\mathrm{HCW}-\mathrm{CCW}) / \mathrm{HCW} \times 100]$ and true yield $[\mathrm{TY}(\mathrm{g} / \mathrm{kg})=(\mathrm{HCW} / \mathrm{GC}) \times 100]$ were determined as described by Cartaxo et al. (2009). Perirenal fat, which was the fat that covered the kidneys, was removed and weighed individually.

In the section between the 13th rib and the 1 st lumbar vertebra, measurements were made to calculate the Longissimus dorsi area (LDA). Geometric measurements were made using digital calipers to measure the width of the eye loin (A), which was the maximum width of the muscle from the medial to the lateral edge of the thoracic and lumbar Longissimus, and the depth (B), which was the maximum distance perpendicular to the width at the location adjacent to the lateral edge of the vertebrae. Then, the LDA was calculated based on the following equation: $(\mathrm{A} / 2 \times \mathrm{B} / 2) \times \pi$, using $\pi=3.14$.

\subsection{Statistical analysis}

The gas production in vitro technique trial was carried out as a completely randomized design in a factorial arrangement $4 \times 17$ (tamarind residue levels $\times$ incubations times) with five replicates (mini-silos) per treatment, according to the mathematical model Yijk $=\mu+\beta i+R j(\beta i)+\tau j+\left(\beta^{*} \tau\right) i j+E i j k$, where Yij = value observed in the treatment and replicate $j$; $\mu=$ general mean; $\beta i=$ effect of treatment $\mathrm{i}=0.00,100,200$ or $300 \mathrm{~g} / \mathrm{kg}$ tamarind residue (as fed); $\mathrm{Rj}(\beta \mathrm{i})=$ random effect based on replication within the treatment; $\tau \mathrm{j}=$ incubation time effect, $\mathrm{j}=2,4,6,8,9,11,12,14,17,20,24,28,34,48,72,96$ and $120 \mathrm{~h} ;(\beta * \tau) \mathrm{ij}=$ effect of the interaction between treatment and incubation time; Eijk = random error.

The silage quality, digestibility and performance trials followed a completely randomized design with 5, 6 and 10 replicates (animals) per treatment, respectively, according to the mathematical model: Yij $=\mu+\alpha i+$ Eij, where Yij $=$ value observed in the treatment and replicate $j ; \mu=$ general mean; $i=$ effect of treatment $i=0.00,100,200$ or $300 \mathrm{~g} / \mathrm{kg}$ tamarind residue (as fed); $\mathrm{j}=$ replicate number; and $\mathrm{Eij}=$ random error.

Statistical analyses were performed using PROC GLM in SAS version 9.0 (SAS, 2013). Analysis of variance was carried out, and an orthogonal partition of the sum of the square of treatments into linear and quadratic degree effects was obtained. The regression equation was adjusted when significance was $P \leq 0.05$ using PROC REG of SAS version 9.0 (SAS, 2013). Trends were discussed at $P \leq 0.05$ to $P \leq 0.10$.

\section{Results}

\subsection{Changes in silages due to the addition of tamarind residue}

The addition of tamarind caused a linear and quadratic increase in the DM $(P<0.001) \mathrm{NDF}_{\text {ap }}(P<0.001)$, ADF $(P<0.001)$, NFC $(P<0.001)$, lignin $(P<0.001)$ and total tannin $(P<0.001)$ contents of the cassava silage (Table 2$)$. In addition, there was a linear and quadratic reduction in the $\mathrm{CP}(P<0.001)$, EE $(P<0.001)$ and ash (linear, $P=0.018$; quadratic, $P=0.044)$ contents of cassava silages produced with the addition of tamarind residue. Linear and quadratic effects were not observed on DM recovery rate and effluent loss in the cassava silages with tamarind residue added.

There were linear and quadratic reductions in silage $\mathrm{pH}(P<0.001)$ and ammonia $\mathrm{N}$ content $(\mathrm{mg} / \mathrm{g} \mathrm{N}$ total $)(P<0.001)$ with the addition of tamarind residue (Table 2). However, there was trend for a linear increase in gas loss $(P=0.059)$ from the cassava silages with tamarind residue added.

\subsection{Results of trials using the in vitro gas production technique}

There was a linear and quadratic increase $(\mathrm{mL} / \mathrm{g} \mathrm{DM})$ in the maximum potential gas production from total carbohydrates (vt) $(P<0.001)$. However, there were also linear and quadratic decreases $(\mathrm{mL} / \mathrm{g} \mathrm{DM})$ in the gas production rate from $\mathrm{NFCs}\left(\mathrm{m}_{1}\right)$ $(P<0.001)$, total gas production rate $(\mathrm{mt})(P<0.001)$, hours in the lag phase $(P<0.001)$ and the in vitro dry matter digestibility kinetics over $48 \mathrm{~h}$ (IVDMD) $(P<0.001)$ of the cassava silages with the inclusion of tamarind residue (Table 3 ). There were no effects of tamarind residue inclusion in cassava silage $(\mathrm{mL} / \mathrm{g} \mathrm{DM})$ on the gas production rate from NFCs $\left(\mathrm{vf}_{1}\right)$ or gas production rates from 
Table 3

Gas production and in vitro dry matter degradability kinetics of ruminal fermentation of cassava silage with tamarind residue added at different levels.

\begin{tabular}{|c|c|c|c|c|c|c|c|}
\hline \multirow[t]{2}{*}{ Variables } & \multicolumn{4}{|c|}{ Tamarind residue ( $\mathrm{g} / \mathrm{kg}$ as fed) } & \multirow[t]{2}{*}{$\mathrm{SEM}^{\mathrm{a}}$} & \multicolumn{2}{|l|}{$P$ - value } \\
\hline & 0.00 & 100 & 200 & 300 & & Linear & Quadratic \\
\hline $\mathrm{vf}_{1}(\mathrm{~mL} / \mathrm{g} \mathrm{DM})^{\mathrm{b}}$ & 47.9 & 49.5 & 55.4 & 49.3 & 1.08 & 0.32 & 0.11 \\
\hline $\mathrm{vf}_{2}(\mathrm{~mL} / \mathrm{g} \mathrm{DM})^{\mathrm{c}}$ & 26.0 & 24.6 & 26.1 & 31.4 & 1.11 & 0.075 & 0.055 \\
\hline $\mathrm{m}_{1}(\mathrm{~mL} / \mathrm{g} \mathrm{DM})^{\mathrm{d}}$ & 0.12 & 0.11 & 0.10 & 0.07 & 0.01 & $<0.001$ & $<0.001$ \\
\hline $\mathrm{m}_{2}(\mathrm{~mL} / \mathrm{g} \mathrm{DM})^{\mathrm{e}}$ & 0.02 & 0.02 & 0.02 & 0.02 & 0.01 & 0.22 & 0.45 \\
\hline vt $(\mathrm{mL} / \mathrm{g} \mathrm{DM})^{\mathrm{f}}$ & 73.9 & 74.1 & 81.5 & 80.7 & 1.03 & $<0.001$ & $<0.001$ \\
\hline $\mathrm{mt}(\mathrm{mL} / \mathrm{g} \mathrm{DM})^{\mathrm{g}}$ & 0.14 & 0.12 & 0.12 & 0.09 & 0.01 & $<0.001$ & $<0.001$ \\
\hline Lag phase (h) & 9.15 & 8.27 & 7.72 & 6.43 & 0.97 & $<0.001$ & $<0.001$ \\
\hline $\operatorname{IVDMD}(\mathrm{g} / \mathrm{kg})^{\mathrm{h}}$ & 781 & 684 & 679 & 624 & 1.50 & $<0.001$ & $<0.001$ \\
\hline
\end{tabular}

${ }^{\mathrm{b}}$ Maximum potential gas production from non-fibrous carbohydrates.

${ }^{\text {a }}$ Standard error of the mean.

${ }^{\mathrm{c}}$ Maximum potential gas production from fibrous carbohydrates.

${ }^{\mathrm{d}}$ Gas production rates from non-fibrous carbohydrates.

e Gas production rates from fibrous carbohydrates.

${ }^{f}$ Maximum potential gas production from total carbohydrates.

$\mathrm{g}$ Total gas production rate.

${ }^{\mathrm{h}}$ In vitro dry matter digestibility kinetics over $48 \mathrm{~h}$.

fibrous carbohydrates (FCs) $\left(\mathrm{m}_{2}\right)$. There was a linear increase in gas production of $27.0 \mathrm{~mL} / \mathrm{g} \mathrm{DM}$ of the cassava silage with $300 \mathrm{~g} / \mathrm{kg}$ tamarind residue added.

\subsection{Animal performance}

The inclusion of tamarind residue in the cassava silage had no effect on the intake $(\mathrm{g} / \mathrm{d})$ of DM, CP, NFCs or total digestible nutrients (TDNs). However, there was a linear increase in NDF intake $(P=0.042)$ and a linear reduction in EE $(P=0.038)$ intake by lambs fed cassava silage with added tamarind residue. There were no quadratic effects on NDF or EE intake, but there were linear increases in the DM intake (DMI; $\mathrm{g} / \mathrm{kg}$ BW) $(P<0.001)$ and $\mathrm{NDF}_{\mathrm{ap}}(P<0.001)$ in lambs fed cassava silage with tamarind residue added. In addition, there were quadratic effects on the DMI and NDF intake ( $\mathrm{g} / \mathrm{kg} \mathrm{BW})$ of the animals.

There were positive linear and quadratic effects on the DMDC $(P<0.001), \mathrm{CP}(P<0.001)$ and reduction of $\mathrm{NDF}_{\mathrm{ap}}$ $(P<0.001)$ (Table 4$)$ and positive quadratic effects on NFC $(P=0.066)$ and EE $(P=0.018)$ digestibility due to the inclusion of

Table 4

Feed intake and the coefficients of digestibility and nitrogen balance of lambs fed cassava silage with tamarind residue added at different levels.

\begin{tabular}{|c|c|c|c|c|c|c|c|}
\hline \multirow[t]{2}{*}{ Item } & \multicolumn{4}{|c|}{ Tamarind residue ( $\mathrm{g} / \mathrm{kg}$ as fed) } & \multirow[t]{2}{*}{ SEM $^{\mathrm{a}}$} & \multicolumn{2}{|l|}{$P$-value } \\
\hline & 0.00 & 100 & 200 & 300 & & Linear & Quadratic \\
\hline \multicolumn{8}{|l|}{ Daily feed intake (g/day) } \\
\hline Dry matter & 1011 & 1098 & 1115 & 1144 & 96.9 & 0.32 & 0.75 \\
\hline Crude protein & 152 & 167 & 170 & 175 & 13.8 & 0.28 & 0.73 \\
\hline Neutral detergent fiber & 287 & 331 & 349 & 370 & 28.6 & 0.042 & 0.68 \\
\hline Non-fibrous carbohydrates & 450 & 474 & 479 & 484 & 38.9 & 0.54 & 0.81 \\
\hline Ether extract & 39.2 & 34.3 & 32.0 & 31.1 & 2.66 & 0.038 & 0.45 \\
\hline Total digestible nutrients & 745 & 806 & 818 & 766 & 63.2 & 0.79 & 0.38 \\
\hline \multicolumn{8}{|l|}{ Daily feed intake (g/kg BW) } \\
\hline Dry matter & 32.8 & 36.5 & 35.2 & 38.9 & 0.50 & $<0.001$ & 0.97 \\
\hline Neutral detergent fiber & 9.70 & 11.5 & 11.6 & 13.2 & 0.20 & $<0.001$ & 0.76 \\
\hline \multicolumn{8}{|l|}{ Digestibility coefficient } \\
\hline Dry matter & 0.74 & 0.75 & 0.75 & 0.67 & 0.015 & $<0.001$ & $<0.001$ \\
\hline Crude protein & 0.52 & 0.61 & 0.54 & 0.40 & 0.019 & $<0.001$ & $<0.001$ \\
\hline Neutral detergent fiber & 0.59 & 0.56 & 0.60 & 0.49 & 0.022 & $<0.001$ & 0.10 \\
\hline Non-fibrous carbohydrates & 0.92 & 0.94 & 0.94 & 0.91 & 0.014 & 0.55 & 0.066 \\
\hline Ether extract & 0.68 & 0.74 & 0.70 & 0.64 & 0.024 & 0.19 & 0.018 \\
\hline \multicolumn{8}{|l|}{ Nitrogen Balance (g/d) } \\
\hline $\mathrm{N}$ Intake & 26.1 & 26.9 & 28.1 & 28.0 & 1.06 & 0.40 & 0.78 \\
\hline Fecal N excretion & 9.54 & 7.87 & 10.0 & 14.1 & 0.79 & $<0.001$ & 0.029 \\
\hline Urinary $\mathrm{N}$ excretion & 9.39 & 10.5 & 10.2 & 8.61 & 0.35 & 0.31 & 0.018 \\
\hline N Retained & 7.13 & 8.59 & 7.82 & 5.27 & 0.35 & $<0.001$ & $<0.001$ \\
\hline
\end{tabular}

\footnotetext{
${ }^{\text {a }}$ Standard error of the mean.
} 
Table 5

Performance and carcass characteristics of castrated lambs fed cassava silage with tamarind residue added at different levels.

\begin{tabular}{|c|c|c|c|c|c|c|c|}
\hline \multirow[t]{2}{*}{ Variables } & \multicolumn{4}{|c|}{ Tamarind residue ( $\mathrm{g} / \mathrm{kg}$ as $\mathrm{fed}$ ) } & \multirow[t]{2}{*}{$\mathrm{SEM}^{\mathrm{a}}$} & \multicolumn{2}{|l|}{$P$ - value } \\
\hline & 0.00 & 100 & 200 & 300 & & Linear & Quadratic \\
\hline Initial body weight (kg) & 21.2 & 22.6 & 21.5 & 23.2 & - & - & - \\
\hline Final body weight (kg) & 29.7 & 30.7 & 31.3 & 30.9 & 0.61 & 0.21 & 0.33 \\
\hline Average daily gain $(\mathrm{g} / \mathrm{d})$ & 105 & 119 & 127 & 122 & 4.90 & 0.21 & 0.33 \\
\hline Feed conversion $(\mathrm{g} / \mathrm{g})^{\mathrm{b}}$ & 9.57 & 9.80 & 9.16 & 10.2 & 0.33 & 0.60 & 0.44 \\
\hline Hot carcass weight (kg) & 15.6 & 16.1 & 17.2 & 16.9 & 0.38 & $<0.001$ & 0.28 \\
\hline Hot carcass yield (g/kg) & 524 & 526 & 549 & 546 & 3.60 & $<0.001$ & 0.65 \\
\hline Cold carcass weight (kg) & 15.1 & 15.6 & 16.6 & 16.4 & 0.37 & $<0.001$ & 0.37 \\
\hline Cold carcass yield $(\mathrm{g} / \mathrm{kg})$ & 508 & 509 & 530 & 530 & 3.40 & $<0.001$ & 0.94 \\
\hline True yield $(\mathrm{g} / \mathrm{kg})$ & 601 & 601 & 621 & 609 & 3.20 & 0.12 & 0.45 \\
\hline Cooking weight losses $(\mathrm{g} / \mathrm{kg})$ & 30.2 & 31.9 & 35.0 & 29.1 & 3.20 & 1.00 & 0.25 \\
\hline Perirenal fat $(\mathrm{kg})$ & 1.03 & 1.13 & 1.07 & 1.29 & 0.06 & 0.16 & 0.90 \\
\hline Longissimus dorsi area (cm) & 9.43 & 10.6 & 10.9 & 11.4 & 0.26 & $<0.001$ & 0.20 \\
\hline
\end{tabular}

a Standard error of the mean.

${ }^{\mathrm{b}}$ Feed/gain ratio.

tamarind residue in cassava silage.

The addition of tamarind residue in cassava silage resulted in a linear and quadratic increase in fecal $\mathrm{N}$ excretion (linear, $P<0.001$; quadratic, $P=0.029)$ and a quadratic increase in urinary $\mathrm{N}$ excretion $(P=0.018)$ in lambs. For retained $\mathrm{N}(P<0.001)$ in lambs, the results were the opposite: a linear and quadratic reduction was observed with the inclusion of tamarind residue in cassava silage. There was no linear or quadratic effect of tamarind residue inclusion in cassava silage on $\mathrm{N}$ intake.

There were no linear or quadratic effects in relation to the levels of tamarind residue included in the cassava silage on final body weight, average daily weight gain, feed conversion (feed/gain), true carcass yield, cooking loss and perirenal fat (Table 5). However, HCW $(P<0.001)$, HCY $(P<0.001)$, CCW $(P<0.001)$, CCY $(P<0.001)$ and LDA $(P<0.001)$ all showed a linear increase with increased inclusion levels of tamarind residue in the cassava silage, whereas there were no quadratic effects in relation to the different diets.

\section{Discussion}

\subsection{Silage}

The absorptive effect of tamarind residue was demonstrated by the greater levels of DM in the cassava silages. The ideal level of DM in silage described by McDonald et al. (1991) is approximately 280-350 g/ kg. A value in this range was observed with the inclusion of tamarind residue at $100 \mathrm{~g} / \mathrm{kg}$ (DM of silage $=318 \mathrm{~g} / \mathrm{kg}$ ), and the DM content was even greater with the addition of tamarind residue at $300 \mathrm{~g} / \mathrm{kg}$ to the silage (DM of silage $=448 \mathrm{~g} / \mathrm{kg}$ ). Therefore, tamarind residue functioned as an absorptive additive by adjusting the DM content of the cassava silage to levels that enabled proper fermentation to occur. This was beneficial because it prevented the high humidity needed for the development of bacteria from the genus Clostridium responsible for butyric fermentation, which is the main cause of losses in silage (McDonald et al., 1991).

However, the inclusion of tamarind residue at $300 \mathrm{~g} / \mathrm{kg}$ cassava silage had some negative effects on the silage, such as a reduction in the CP $(80 \mathrm{~g} / \mathrm{kg}), \mathrm{EE}(20 \mathrm{~g} / \mathrm{kg})$ and ash $(30 \mathrm{~g} / \mathrm{kg})$ contents and increases in the $\mathrm{NDF}_{\mathrm{ap}}(90 \mathrm{~g} / \mathrm{kg}), \mathrm{ADF}(90 \mathrm{~g} / \mathrm{kg})$ and lignin (125 g/ $\mathrm{kg}$ ) contents, as well as in the tannin $(28 \mathrm{GAE} / \mathrm{g} \mathrm{DM})$ content; tannins are phenolic, non-nutritional components in the diets of ruminants that limit the ruminal degradation of the fibrous fraction of feed and impair CP digestibility.

Furthermore, silage with a high level of CP is beneficial because it allows for increased proteolysis, which results in a buffering effect that hinders the reduction of the $\mathrm{pH}$ to levels that are optimum for fermentation (Napasirth et al., 2015). In addition, the ammonia content of the silage was also reduced by $12 \mathrm{mg} / \mathrm{g} \mathrm{N}$ with the addition of tamarind residue and ranged from 41.2 to $29.3 \mathrm{mg} / \mathrm{g} \mathrm{N}$. The ammonia $\mathrm{N}$ level reflects the extent of proteolysis during fermentation in the silo. However, the reduction of ammonia indicates that protein preservation during acidogenesis, which is a relevant outcome because cassava has a high protein content (205 g/kg). Van Soest (1994) reported that values of ammonia $\mathrm{N}$ below $100 \mathrm{mg} / \mathrm{g}$ of total $\mathrm{N}$ are considered adequate for fermentation.

The increase in the $\mathrm{NDF}_{\mathrm{ap}}$ and $\mathrm{ADF}$ values is very important, as the levels of these components indicate the degree of degradability of forage, which according to Van Soest (1994) can limit the DMI of animals via physical mechanisms. Forage with NDF levels greater than $600 \mathrm{~g} / \mathrm{kg}$ is considered to be of low quality. The present results show that despite the increase in residue levels, $\mathrm{NDF}_{\text {ap }}$ from tamarind residue $(550 \mathrm{~g} / \mathrm{kg}$ ) remained below the maximum limits recommended for high-quality silage.

The inclusion of tamarind residue resulted in $\mathrm{pH}$ values ranging from 4.04 to 3.85, which are acceptable for providing aerobic stability in the silage because suitable $\mathrm{pH}$ values range from 3.8 to 4.2 (Massafera et al., 2015). This reduction in pH was also promoted by the increase in NFC $(180 \mathrm{~g} / \mathrm{kg})$ content, which put this parameter at the minimum threshold for changing the type of fermentation. This reduction also promoted increased effluent and gas losses. 


\subsection{Trial using the in vitro gas production technique}

The vt increased, probably due to the carbohydrate content present in cassava waste. With the addition of tamarind residue, there was an increase in the fermentable substrate in the cassava silage. This is because the fermentation of FCs, such as cellulose and hemicellulose, produces a greater proportion of acetate, which results in a greater proportion of substrates that can be used by methanogenic bacteria (Medeiros et al., 2015; Morais et al., 2015). This occurs because the rumen microbial degradation of carbohydrates converts them primarily to glucose-1-P, which is subsequently oxidized to pyruvic acid by the Embden-Meyerhof cycle and thereafter to acetate and propionate by the action of the pyruvate lyase enzyme (Van Soest, 1994).

There was a reduction of $0.14 \mathrm{~mL}$ of gas produced from NFCs " $\mathrm{m}_{1}$ " $(\mathrm{ml} / \mathrm{g} \mathrm{DM})$ with the inclusion of $100 \mathrm{~g} / \mathrm{kg}$ tamarind residue in cassava silage. The reduction in the NFC gas production rate occurred because there was a marked increase in fiber content and ADL with the inclusion of tamarind residue. The greatest gas production rate occurred at the initial stage of fermentation when the high concentration of NFC resulted in an increased fermentation rate. Over time, these components became scarce, and the remaining energy source, NDF, was fermented at a slower rate (Napasirth et al., 2015).

There was a reduction of $\mathrm{mt}(\mathrm{ml} / \mathrm{g} \mathrm{DM})$ of $0.16 \mathrm{~mL}$ with the inclusion of $100 \mathrm{~g} / \mathrm{kg}$ tamarind residue in the cassava silage. The decrease can be explained by the increase in tannins in the residue complexing with proteins, which may reduce the availability of nutrients for fermentation and consequently depress the rate of carbohydrate degradation (Vázquez et al., 2016; Wang et al., 2016). This fact also explains the reduction that occurred in DMD in vitro.

Phase latency or lag time is the time between the start of incubation and the start of microbial action in an incubated sample and is related to the degradation of fibers (Silva et al., 2015b). This parameter showed a linear effect, which can be attributed to the NFC content of the residue (268 g/kg). According to Mertens (2002), NFC, which is represented by water-soluble sugars (mono and disaccharides), starch and pectin, are fermented quickly and are completely digestible in the gastrointestinal tract, which results in shorter colony growth times due to the rapid degradation and fermentation of this soluble fraction.

\subsection{Animal performance}

The increase of $200 \mathrm{~g} / \mathrm{kg}$ in the DMI of the animals receiving silage with greater levels of included tamarind residue was due to an increase of $400 \mathrm{~g} / \mathrm{kg}$ in the DM content of the silage. This shows that the increases in the fiber and the phenolic (lignin and tannin) contents caused by the inclusion of the tamarind residue in the silage did not cause a physical decrease in DMI (Bezerra et al., 2015).

The inclusion of tamarind residue in cassava silage, up to $300 \mathrm{~g} / \mathrm{kg}$ of DM, increased DMI to $38.9 \mathrm{~g} / \mathrm{kg}$ of BW, which is above the intake recommended (approximately $30 \mathrm{~g} / \mathrm{kg}$ BW) by the NRC (2007). Ben Salem et al. (2000a) emphasized that tannins interfere with voluntary DMI, which suggests that the effects found in this study may have been minimized by the use of solid waste (tamarind residue) in cassava silage, which according to McSweeney et al. (2001) reduces the effects of tannins in the diet because of the acidic and anaerobic conditions of the silage.

The inclusion of tamarind residue in cassava silage at levels up to $200 \mathrm{~g} / \mathrm{kg}$ of the total DM in the diets of lambs contributed to an increased efficiency in DM digestibility. However, greater levels tended to depress the digestibility of this fraction, possibly due to the increases in tannin and lignin concentrations, which can have toxic effects on ruminal microorganisms (Geron et al., 2015). According to Orlandi et al. (2015), increasing dietary levels of tannin significantly decreased the apparent nutrient digestibility. Wang et al. (2016) observed that the digestibility of DM, CP, and EE was $570 \mathrm{~g} / \mathrm{kg}, 870 \mathrm{~g} / \mathrm{kg}$ and $860 \mathrm{~g} / \mathrm{kg}$, respectively, when tamarind residue was included in sheep diets, and a higher level $(832 \mathrm{~g} / \mathrm{kg})$ of NFC digestibility was observed. However, according to Hristov et al. (2013), beneficial results can be achieved when tannins are added to the diets of ruminants at appropriate levels that favor and promote increased efficiency in the ruminal digestion process.

The inhibitory properties of tannins depend on the total concentration of proteins (Patra and Saxena, 2011). The mechanism postulated to tannin content is that tannins complex proteins at the $\mathrm{pH}$ of the rumen and protect them from microbial enzymes. Thus, there is an increase in the efficiency of microbial protein synthesis and a decrease in the feed protein degradability (Van Soest, 1994), that is beneficial for ruminants as they increase the supply of non-ammonia $\mathrm{N}$ to the lower intestine (Makkar, 2003). The duodenal flux of all amino acids is evidently improved by tannins (Theodoridou et al., 2010). These effects lead to protein-sparing effects in ruminants, reductions in methane production (Hassanat and Benchaar, 2013) and N excretion to the environment (Lapierre et al., 2012), which thereby reduce the emission of environmental pollutants. In addition, tannins can form complexes with indigestible cell-wall carbohydrates and can bind to bacterial enzymes, by which they reduce the activities of ruminal microorganisms such as cellulolytic bacteria (Geron et al., 2015; Gonçalves et al., 2015).

TDN intake ranged from 745 to $818 \mathrm{~g} /$ day at levels of $0-300 \mathrm{~g} / \mathrm{kg}$ tamarind residue included in the cassava silage, respectively. Microbial protein production and flow into the abomasum is related to the use of TDNs. According to the NRC (1996), for each 100 $\mathrm{g}$ of TDN intake, $13 \mathrm{~g}$ of microbial proteins is produced. Thus, it was estimated that for diets containing $0.00,100,200 \mathrm{and} 300 \mathrm{~g} / \mathrm{kg}$ of tamarind residue, 97.0, 115, and 112, and $109 \mathrm{~g}$ of microbial CP, respectively, would be produced per day in the duodenum. Based on this information, it is expected that the addition of tamarind residue in cassava silage contributes to muscle growth and consequently to better animal performance.

The lack of effect on body weight at slaughter can be explained by the fact that animals presented similar average daily weight gains and did not show an effect of diet on feed conversion. In another analysis, it was possible to infer that there was a more efficient use of the retained $\mathrm{N}$ because, even with the lower $\mathrm{N}$ retention levels in lamb fed the diets with the highest levels of tamarind residue, the animals gained similar amounts of weight at all inclusion levels (Agy et al., 2012). Moderate concentrations (20 and $40 \mathrm{~g} / \mathrm{kg}$ in DM basis) of condensed tannins may benefit the nutrition and health of small ruminants (Ben Salem et al., 2000b). This is because at 
these levels, tannins bind to certain proteins and protect them from excessive ruminal degradation (Hassanat and Benchaar, 2013). These tannin-bound proteins pass through the rumen and are released into the duodenum, the portion of the gastrointestinal tract in which the absorption of amino acids occurs more intensely, which results in better utilization of dietary protein (Theodoridou et al., 2010). Diets with greater amounts of tannins, due to the inclusion of tamarind residue in the ensiling process, influence the parameters of ruminal kinetics, with a reduction in gas production rates that results in lower energy loss from animals in the form of gases lost to the environment. This indicates a greater increase in weight in the form of muscle and body fat and thus affects carcass yield (Wang et al., 2016). Note that the HCY and CCY were obtained through mathematical calculations involving the live weight at slaughter after fasting, empty body weight, HCW and CCW. Depending on dietary passage rates, the HCY and CCY vary as a function of gastrointestinal tract filling (Oliveira et al., 2015b).

\section{Conclusions}

The addition of $300 \mathrm{~g} / \mathrm{kg}$ tamarind residue in the ensiling of cassava improves the quality of cassava silage because it increases the $\mathrm{DM}$ content and reduces the production of gases. Therefore, the inclusion of tamarind residue in the ensiling of cassava in lamb diets is recommended because including this silage as roughage (500 g/ $\mathrm{kg}$ of feed) contributes to increased DMI and DM digestibility, $\mathrm{N}$ retention, HCY, CCY, and LDA.

\section{Conflict of interest}

The authors have no conflicts of interest to declare.

\section{Acknowledgments}

The research was supported by the National Council for Scientific and Technological Development (Brazil), by the Coordination for the Improvement of Greater Education Personnel, and by the Bahia State Research Foundation and Federal University of São Francisco Valley, Pernambuco State, Brazil.

\section{References}

AOAC, 1990. Official Methods of Analysis, 15th ed. Association of Official Analytical Chemists, Arlington, VA.

AOAC, 2002. Methods of Analysis, 17th ed. Association of Official Analytical Chemists, Arlington, VA.

Agy, M.S.F.A., Oliveira, R.L., Ribeiro, C.V.D.M., Ribeiro, M.D., Bagaldo, A.R., de Araújo, G.G.L., Pinto, L.F.B., Ribeiro, R.D.X., 2012. Sunflower cake from biodiesel production fed to crossbred Boer kids. R. Bras. Zootecn. 41, 123-130.

Ampapon, T., Wanapat, M., Kang, S., 2016. Rumen metabolism of swamp buffaloes fed rice straw supplemented with cassava hay and urea. Trop. Anim. Health Prod. 48, 779-784.

Ben Salem, H.B., Nefzaoui, A., Ben Salem, L., Tisserand, J.L., 2000a. Deactivation of condensed tannins in Acacia cyanophyllaLindl. foliage by polyethylene glycol in feed blocks Effect on feed intake, diet digestibility, nitrogen balance, microbial synthesis and growth by sheep. Livest. Sci. Prod. 64, 51-60.

Ben Salem, H., Nefzaoui, A., Ben Salem, L., 2000b. Deactivation of condensed tannins in Acacia cynophylla (A. saligna) Lindl. forage by polyethylene glycol in feed block effect on feed intake, diet digestibility, N balance, microbial synthesis and growth by sheep. Nutrition of sheep and goats. Treacher, T.T. (Ed.), Livest. Prod. Sci. 48, 51-60.

Bezerra, L.R., Edvan, R.L., Oliveira, R.L., Silva, A.M.A., Bayao, G.F.V., Oliveira, W.D.C., Pereira, F.B., 2015. Hematobiochemical profile and milk production of crossbred Girolando cows supplemented with product dry cashew. Semina: Ci. Agr. 36, 3329-3340.

Bolsen, K.K., Lin, C., Brent, B.E., Feyerherm, A.M., Urban, J.E., Aimutis, W.R., 1992. Effect of silage additives on the microbial succession and fermentation process of alfalfa and corn silages. J. Dairy. Sci. 75, 3066-3083.

Cartaxo, F.Q., Cezar, M.F., Sousa, W.H., GonzagaNeto, S., Pereira Filho, J.M., Cunha, M.G.G., 2009. Quantitative traits of carcass from lambs finished in feedlot system and slaughtered at different body conditions. Rev. Bras. Zootecn. 38, 697-704.

Fernandes, F.D., Guimarães Júnior, R., Vieira, E.A., de F. Fialho, J., Malaquias, J.V., 2016. Yield and nutritional value of shoots and tuberous roots of eight industry cassava genotypes. Rev. Bras. Saúde Prod. Anim. 17, 1-12.

Geron, L.J.V., da Costa, F.G., de Aguiar, S.C., Garcia, J., Ribeiro, M.G., Zeoula, L.M., Silva, A.P., da Pereira, S.R., Silveira, R.M., 2015. In vitro and in vivo nutrient digestibility in sheep of rations with and without residue from the extraction of tamarind pulp. Semina: Ci. Agr. 36, 4507-4517.

Gonçalves, J.A.G., Zambom, M.A., Fernandes, T., dos Tinini, R.C.R., Schimidt, E.L., Castagnara, D.D., de Canabarro, L.O., da Cruz, E.A., 2015. Silage from residue from extraction of cassava starch in substitution of ground corn in sheep feed. Rev. Bras. Saçde Prod. Anim. 16, 839-849.

Gonzaga Neto, S., Oliveira, R.L., Lima, F.H., Medeiros, A.N., Bezerra, L.R., Viégas, J., Nascimento Jr, N.G., Freitas Neto, M.D., 2015. Milk production, intake, digestion, blood parameters, and ingestive behavior of cows supplemented with by-products from the biodiesel industry. Trop. Anim. Health Prod. 47, $191-200$.

Hassanat, F., Benchaar, C., 2013. Assessment of the effect of condensed (acacia and quebracho) and hydrolysable (chestnut and valonea) tannins on rumen fermentation and methane production in vitro. J. Sci. Food Agric. 93, 332-339.

Hristov, A.N., Oh, J., Firkins, J.L., Dijkstra, J., Kebreab, E., Waghorn, G., Tricarico, J.M., 2013. Special Topics-mitigation of methane and nitrous oxide emissions from animal operations: i: A review of enteric methane mitigation options. J. Anim. Sci. 91, 5045-5069.

Jobim, C.C., Nussio, L.G., Reis, R.A., Schmidt, P., 2007. Methodological advances in evaluation of preserved forage quality. Rev. Bras. Zootecn. 36, 101-119.

Lapierre, H., Lobley, G.E., Doepel, L., Raggio, G., Rulquin, H., Lemosquet, S., 2012. Triennial lactation symposium: mammary metabolism of amino acids in dairy cows. J. Anim. Sci. 90, 1708-1721.

Licitra, G., Hernandez, T.M., Van Soest, P.J., 1996. Standardization of procedures for nitrogen fractionation of ruminant feeds. Anim. Feed Sci. Technol. 57, 347-358.

Makkar, H.P.S., 2003. Effects and fate of tannins in ruminant animals, adaptation to tannins, and strategies to overcome detrimental effects of feeding tannin-rich feeds. Small Rum. Res. 49, 241-256.

Massafera, D.A., Florentino, L.A., Rabelo, C.H.S., Härter, C.J., Rezende, A.V., Reis, R.A., 2015. Replacement of aruana grass by gliricidia (Gliricidia sepium) on silage quality. Rev. Bras. Zootecn. 44, 231-239.

Mauricio, R.M., Pereira, L.G.R., Gonçalves, L.C., 2003. Relationship between volume and pressure for installation of the semi-automated in vitro gas production technique for tropical forage evaluation. Arq. Bras. Med. Vet. Zoo. 55, 216-219.

McDonald, P., Henderson, A.R., Heron, S., 1991. The Biochemistry of Silage, 2nd edn. Marlow, Chalcombe (340p).

McSweeney, C.S., Palmer, B., Mcneill, D.M., Krause, D.O., 2001. Microbial interactions with tannins: nutritional consequences for ruminants. Anim. Feed Sci. Tech. 91, 
83-93.

Medeiros, F.F., Silva, A.M.A., Carneiro, H., Araújo, D.R.C., Morais, R.K.O., Moreira, M.N., Bezerra, L.R., 2015. Alternative protein sources derived from the biodiesel production chain for feeding to ruminants. Arq. Bras. Med. Vet. Zootec. 67, 519-525.

Menezes, D.R., Costa, R.G., Araújo, G.G.L., Pereira, L.G.R., Nunes, A.C.B., Henriques, L.T., Rodrigues, R.T.S., 2015. Ruminal kinetics of diets containing detoxicated castor bean meal. Arq. Bras. Med. Vet. Zoo. 67, 636-641.

Mertens, D.R., 1997. Creating a system for meeting the fiber requirements of dairy cows. J. Dairy. Sci. 80, $1463-1481$.

Mertens, D.R., 2002. Gravimetric determination of amylase-treated neutral detergent fiber in feeds with refluxing in beakers or crucibles: collaborative study. J. AOAC Int. 85, 1217-1240.

Morais, R.K.O., Silva, A.M.A., Bezerra, L.R., Carneiro, H., Moreira, M.N., Medeiros, F.F., 2015. In vitro degradation and total gas production of byproducts generated in the biodiesel production chain. Acta-Sci. Anim. Sci. 37, 143-148.

NRC, 1996. Nutrient Requirements of Beef Cattle, 7th revised edn. Natl. Acad. Press, Washington, DC.

NRC, 2007. Nutrient Requirements of Small Ruminants: Sheep, Goats, Cervids and New World Camelids. Natl. Acad. Press, Washington, DC.

Napasirth, V., Napasirth, P., Sulinthone, T., Phommachanh, K., Cai, Y., 2015. Microbial population, chemical composition and silage fermentation of cassava residues. Anim. Sci. J. 86, 842-848.

Oliveira, R.L., Faria, M.M.S., Bezerra, L.R., Carvalho, G.G.P., Pinheiro, A., Simionato, J., Leao, A.G., 2015a. Fatty acid profile of milk and cheese from dairy cows supplemented a diet with palm kernel cake. Molecules 20, 15434-15448.

Oliveira, R.L., Palmieri, A.D., Carvalho, S.T., Leão, A.G., Abreu, C.L., Ribeiro, C.V.D.M., Pereira, E.S., Carvalho, G.G.P., Bezerra, L.R., 2015b. Commercial cuts and chemical and sensory attributes of meat from crossbred Boer goats fed sunflower cake-based diets. Anim. Sci. J. 86, 557-562.

Orlandi, T., Kozloski, G.V., Alves, T.P., Mesquita, F.R., Ávila, S.C., 2015. Digestibility, ruminal fermentation and duodenal flux of amino acids in steers fed grass forage plus concentrate containing increasing levels of Acacia mearnsii tannin extract. Anim. Feed Sci. Technol. 210, 37-45.

Patra, A.K., Saxena, J., 2011. Exploitation of dietary tannins to improve rumen metabolism and ruminant nutrition. J. Sci. Food Agric. 91, 24-37.

Polyorach, S., Wanapat, M., Cherdthong, A., Kang, S., 2016. Rumen microorganisms, methane production, and microbial protein synthesis affected by mangos teen peel powder supplement in lactating dairy cows. Trop. Anim. Health Pro. 48, 593-601.

Robertson, J.B., Van Soest, P.J., 1981. The detergent system of analysis and its application to human food. In: James, W.P.T., Theander, O. (Eds.), The Analysis of Dietary Fiber in Food. Marcel Dekker, New York, NY, USA, pp. 123-158.

Santos, V.L.F., Ferreira, M.A., Santos, G.T., Damasceno, J.C., Oliveira, K., Agostino, B.C., Olivo, P.M., Soares, L.F.P., Silva, J.L., 2015. Cassava peel as a replacement for corn in the diet of lactating cows. Trop. Anim. Health Pro. 47, 779-781.

SAS, SAS/STAT Software Release 6.12. SAS Institute Inc; Cary, NC, USA, 2003.

Schofield, P., Pitt, R.E., Pell, A.N., 1994. Kinetics of fibre digestion from in vitro gas production. J. Anim. Sci. 72, $2980-2991$.

Silva, M.D.A., Carneiro, M.S., de, S., Pinto, A.P., Pompeu, R.C.F.F., Silva, D.S., Coutinho, M.J.F., Fontenele, R.M., 2015a. Evaluation of the chemical composition of woody forage silages of the Brazilian semiarid. Semina: Ci. Agr. 36, 571-578.

Silva, A.L., Marcondes, M.I., Veloso, C.M., Sousa, F.C., Knupp, L.S., 2015b. Simulation of rumen fermentation kinetics of by-products from the biodiesel industry with in vitro gas production technique. Semina: Ci. Agr. 36, 3851-3862.

Singleton, V.L., Rossi, J.A., 1965. Colorimetry of total phenolics with phosphomolybdic-phosphotungstic-acid reagents. Am. J. Enol. Viticul. 16, 144-168.

Tamilselvi, P., Krishnamoorthy, R., Dhamotharan, P., Arumugam, E., Sagadevan, 2012. Analysis of total phenols, total tannins and screening of phytocomponents in Indigoferaaspalathoides (ShivanarVembu) Vahl EX DC. J. Chem. Pharm. Res. 4, 3259-3262.

Theodoridou, K., Aufrère, J., Andueza, D., Pourrat, J., Le Morvan, A., Stringano, E., Mueller-Harvey, I., Baumont, R., 2010. Effects of condensed tannins infresh sainfoin (Onobrychisviciifolia) on in vivo and in situ digestion in sheep. Anim. Feed Sci. Technol. 160, 23-38.

Theodorou, M.K., Williams, B.A., Dhanoa, M.S., 1994. A simple gas production method using a pressure transducer to determine the fermentation kinetics of ruminant feeds. Anim. Feed Sci. Tech. 48, 185-197.

Vázquez, E.G., Medina, L.H., Benavides, L.M., Caratachea, A.J., Razo, G.S., Burgos, A.J.A., Rodríguez, R.O., 2016. Effect of fodder tree species with condensed tannin contents on In vitro methane production. Asian-Aus. J. Anim. Sci. 29, 73-79.

Van Soest, P.J., Robertson, J.B., Lewis, B.A., 1991. Methods for dietary fiber, neutral detergent fiber, and nonstarchpolyssacharides in relation to animal nutrition. J. Dairy Sci. 74, 3583-3597.

Van Soest, P.J., 1994. Nutritional Ecology of the Ruminant, 2. ed. Cornell University Press, Ithaca (476p).

Wang, L., Nakanishi, T., Sato, Y., Oishi, K., Hirooka, H., Takahashi, K., Kumagai, H., 2016. Effect of feeding tamarind kernel powder extract residue on digestibility, nitrogen availability and ruminal fermentation in wethers. Asian-Aus. J. Anim. Sci. http://dx.doi.org/10.5713/ajas.16.0137. 